\title{
Profil Penderita Diare Anak Di Puskesmas Rawat Inap Pekanbaru
}

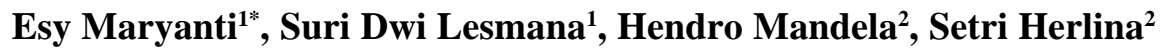

\begin{abstract}
Diarrhea is one of the most frequent diseases of infants and children in the world. In developing countries, diarrhea is still one of the major causes of morbidity and mortality in children. In 2009, the incidence of diarrhea in children in Pekanbaru there were more than 5-6 people per day. Pekanbaru is the densely populated city that is very easy occurrence of diarrhea in children. Many factors affect the incidence of diarrhea in children, one of which is the environment, hygiene and nutritional status of children. This study aims to determined the profile of children with diarrhea in Health Centers Inpatient Pekanbaru. A total of 96 patients of diarrhea in children Pekanbaru Health Center Inpatient obtained most of the male sex (54.2\%), with the age of majority was especially toddlers aged 1-3 years. Nutritional status in patients with diarrhea was generally a good. Stool characteristics in childhood diarrhea patients was mostly mushy, not slimy and does not bleed.
\end{abstract}

Keywords : diarrhea, children, Health Center

Diare pada anak merupakan salah satu permasalahan kesehatan yang penting di negara berkembang termasuk di Indonesia. Diare di Indonesia masih merupakan masalah kesehatan utama karena masih sering menimbulkan Kejadian Luar Biasa (KLB) dan kadang disertai kematian. ${ }^{1}$

Dalam survey Kesehatan Rumah Tangga (SKRT) tahun 2009 diare menempati urutan kedua terbanyak dari penyebab kematian bayi di Indonesia. ${ }^{2}$ Diare adalah pengeluaran tinja yang lunak atau cair dengan frekuensi tiga kali atau lebih perhari dengan atau tanpa darah atau lendir dalam tinja. Diare terdiri atas diare akut dan diare kronis. Diare akut adalah kejadian diare yang berlangsung kurang dari 14 hari. $^{3}$ Kejadian diare akut di Indonesia diperkirakan sekitar 60 juta kasus setiap tahunnya, dan 1-5\% di antaranya berkembang menjadi diare kronis. ${ }^{4}$ Berdasarkan data dari Dinas Kesehatan Provinsi Riau Tahun 2009, kajian dan analisis dari beberapa survei yang dilakukan, angka kesakitan diare pada semua golongan umur adalah 423/1000 penduduk. Episode diare pada golongan balita adalah 1,5 kali per tahun. Angka kematian diare pada semua golongan umur 54/100.000

\footnotetext{
Bagian Parasitologi FK UNRI

Coresponding Author :esy.maryanti@gmail.com

2 Mahasiswa FK UNRI
}

penduduk dan pada balita terjadi 55.000 kematian $(2,5 / 1.000$ balita $){ }^{5}$

Kejadian diare di Pekanbaru berdasarkan data Dinas Kesehatan Kota Pekanbaru, angka kejadian diare pada anak tercatat sebanyak lebih dari 5-6 orang perhari. Data tersebut diperoleh dari 17 Puskesmas yang ada di Pekanbaru pada tahun 2007. ${ }^{2}$ Sebanyak $85 \%$ diare disebabkan oleh virus dan sisanya disebabkan oleh bakteri, parasit, jamur, alergi makanan, keracunan makanan, malabsorbsi makanan dan lain-lain. ${ }^{6}$ Pekanbaru merupakan kota yang berpenduduk padat sehingga sangat mudah terjadinya penularan diare pada anak.

Banyak faktor yang mempengaruhi kejadian diare pada anak. Faktor higiene dan sanitasi merupakan faktor yang dominan karena kebanyakan agen penyebab diare baik bakteri, virus maupun protozoa ditularkan melalui perantaraan vektor mekanik seperti lalat yang banyak terdapat pada seseorang dengan higiene dan sanitasi yang jelek. Higienitas anak balita sangat tergantung pada orang tuanya, sedangkan pada usia yang lebih besar apalagi usia sekolah, higienitas selain orang tua juga tergantung lingkungan sekitarnya termasuk lingkungan sekolah karena pada fase tersebut anak telah mendapatkan informasi yang lebih banyak dari sekolah termasuk informasi tentang kebersihan perorangan. ${ }^{7}$ 
Karakteristik diare pada anak bermacammacam. Biasanya pada anamnesis, karakteristik diare yang khas telah dapat memperkirakan agen penyebab infeksi. Pada diare yang disebabkan oleh virus, pasien mengeluhkan buang air besar cair dan berbau asam, sedangkan pada diare yang disebabkan oleh amuba karakteristik tinja biasanya tinja berlendir, berdarah dan berbau amis, sedangkan pada diare yang disebabkan oleh bakteri tinja berlendir dengan frekuensi defekasi lebih sering daripada yang disebabkan oleh amuba serta berbau busuk. Lain halnya dengan diare yang disebabkan oleh intoleransi laktosa. Biasanya tinja berbau asam, dan tinja keluar menyemprot. Akan tetapi untuk memastikan agen penyebab tetap perlu dilakukan pemeriksaan laboratorium. ${ }^{7}$

Berdasarkan hal tersebut, penulis tertarik untuk melakukan penelitian tentang profil penderita diare anak di Puskesmas rawat inap Pekanbaru.

\section{METODE}

Jenis penelitian ini adalah deskriptif yang menggambarkan kejadian diare anak berdasarkan umur, jenis kelamin, status gizi, dan karakteristik diare. Penelitian dilakukan pada bulan September - Desember 2012. Pengambilan sampel dilakukan di 4 Puskesmas rawat inap Pekanbaru yaitu Puskesmas Rawat Inap Simpang Tiga, Puskesmas Rawat Inap Karya Wanita Rumbai, Puskesmas Rawat Inap Sidomulyo, Puskesmas Rawat Inap Tenayan Raya. Sampel penelitian ini adalah seluruh pasien diare anak di Puskesmas Rawat Inap Pekanbaru yang berobat dari September - Desember 2012.

Penelitian dilakukan dengan mengisi kuesioner tentang identitas pasien anak, meliputi jenis kelamin, umur dan berat badan anak. Pemeriksaan berat badan anak dilakukan ketika anak pertama kali datang ke Puskesmas. Status gizi dinilai berdasarkan berat badan menurut umur yang kemudian dimasukkan kedalam standar WHO NCHS. Status gizi digolongkan kedalam status gizi lebih, baik dan status gizi kurang. Selain itu juga melihat karakteristik tinja anak yang diare.

\section{HASIL}

Hasil penelitian didapatkan sebanyak 96 pasien diare anak yang berasal dari empat Puskesmas rawat inap Pekanbaru. Karakteristik pasien berdasarkan jenis kelamin dan umur dapat dilihat pada tabel 1 .

Tabel 1. Karakteristik sampel berdasarkan jenis kelamin dan umur

\begin{tabular}{ccc}
\hline Karakteristik & N & $\%$ \\
\hline Jenis Kelamin & & \\
$\bullet \quad$ Laki-laki & 52 & $54,2 \%$ \\
$\bullet \quad$ Perempuan & 44 & $45,8 \%$ \\
\hline Umur & & \\
$\bullet \quad 1-3$ tahun & 42 & $43,8 \%$ \\
$\bullet \quad>3-5$ tahun & 35 & $36,4 \%$ \\
$\bullet>5-10$ tahun & 19 & $19,8 \%$ \\
\hline
\end{tabular}

Karakteristik pasien terbanyak yaitu berjenis kelamin laki-laki dengan rentang umur terbanyak yaitu 1-3 tahun seperti terlihat pada tabel 1 . 
Tabel 2. Distribusi frekuensi status gizi pada pasien diare anak.

\begin{tabular}{lcc}
\hline Status gizi & $\mathrm{N}$ & Persentase $(\%)$ \\
\hline - Lebih & 3 & 3,1 \\
Baik & 89 & 92,7 \\
Kurang & 4 & 4,2 \\
\hline Total & 96 & 100.0
\end{tabular}

Status gizi pasien diare anak di empat Puskesmas Rawat Inap Pekanbaru sebagian besar $92,7 \%$ adalah baik dan hanya $4(4,2 \%)$ orang anak yang mempunyai status gizi kurang seperti terlihat pada tabel 2 .
Berdasarkan karakteristik tinja pasien diare anak seperti yang terlihat pada tabel 3, didapatkan konsisitensi sebagian besar tinja anak adalah lembek.

Tabel 3. Karakteristik tinja pasien diare anak ( $\mathrm{N}=96$ )

\begin{tabular}{ccc}
\hline \multicolumn{1}{c}{ Karakteristik } & $\mathrm{N}$ & Persentase(\%) \\
\hline Konsisitensi & & \\
- Lembek & 52 & 54,2 \\
Lendir & 44 & 45,8 \\
- Positif & 10 & 10,4 \\
- Negatif & 86 & 89,6 \\
Darah & & 0 \\
- Positif & 0 & 100 \\
\hline
\end{tabular}

\section{PEMBAHASAN}

Pada hasil penelitian didapatkan jenis kelamin terbanyak yaitu laki-laki dengan rentang umur terbanyak yaitu 1-3 tahun. Hal ini sesuai dengan data dari WHO yang menyatakan $80 \%$ penderita diare adalah anak balita terutama di bawah 2 tahun. ${ }^{8}$ Hal ini disebabkan karena kekebalan alami pada anak usia dibawah 2 tahun belum terbentuk sehingga kemungkinan terjadinya infeksi lebih besar. Hal ini dapat terjadi karena penyapihan atau pemberian makanan tambahan (susu botol dan makanan campuran) yang dimulai ketika umur anak kurang dari 2 tahun sehingga anak-anak sudah terpapar pada pengganti air susu ibu dan makanan tambahan yang kemungkinan pengolahan dan penyajiannya kurang higienis. Higiene lingkungan (air bersih yang dimasak, dot dan botol atau alat lain yang steril) merupakan hal yang penting diperhatikan untuk menghindari kontaminasi makanan oleh kuman, sehingga dapat dicegah berulangnya infeksi dan diare. ${ }^{9}$ Pada usia tersebut anak juga memiliki kebiasaan memasukkan segala sesuatu ke dalam mulut atau yang disebut sebagai fase oral. Bendabenda yang dimasukkan ke dalam mulut dapat menjadi media infeksi mikroorganisme penyebab diare seperti virus, bakteri, jamur dan parasit. ${ }^{10}$

Pada usia 3-5 tahun, anak berisiko terpapar dengan makanan di luar rumah. Pada umur tersebut anak-anak lebih suka makan jajanan mengikuti jejak teman-temannya, padahal pengolahan dan penyajian makanan tersebut kemungkinan kurang higienis yang berakibat pada kontaminasi makanan oleh kuman yang dapat menyebabkan seorang anak menderita diare. Salah satu faktor yang mempunyai 
pengaruh kuat terhadap terjadinya diare pada anak adalah kebiasaan mencuci tangan. Oleh sebab itu anak sebaiknya dibiasakan untuk mencuci tangan sebelum makan. ${ }^{10}$

Pada penelitian ini ditemukan kejadian diare lebih banyak ditemukan pada anak laki-laki dibandingkan dengan anak perempuan. Hal ini sejalan dengan penelitian yang didapatkan oleh Palupi A dkk tahun 2009 di RS Sardjito Yogyakarta, bahwa risiko kesakitan diare pada balita perempuan sedikit lebih rendah dibandingkan balita laki-laki, namun demikian hingga saat ini belum diketahui penyebab pasti pasien laki-laki lebih sering terkena diare dibanding dengan pasien perempuan. ${ }^{9}$

Status gizi pasien diare anak di empat Puskesmas Rawat Inap Pekanbaru sebagian besar 92,7\% adalah baik. Hal ini sesuai dengan penelitian yang didapatkan oleh Primayani D tahun 2009 tentang status gizi pada pasien diare akut di ruang rawat inap anak RSUD SoE Timor Tengah Selatan NTT bahwa sebagian besar anak yang menderita diare akut adalah yang mempunyai status gizi baik. ${ }^{11}$ Hal ini berbeda dengan penelitian Adisasmito W 2007, yang mendapatkan hasill yang bermakna antara status gizi dengan kejadian diare yaitu diare banyak terjadi pada anak dengan status gizi kurang. ${ }^{12}$

Status gizi sangat mempengaruhi terjadinya diare. Malnutrisi telah lama diketahui mempunyai hubungan timbal balik dengan diare. Diare dapat menimbulkan malnutrisi, sebaliknya malnutrisi juga dapat menimbulkan diare. Menurut Departemen Kesehatan RI faktor-faktor yang menyebabkan terjadinya diare pada penderita malnutrisi antara lain: atrofi vilus usus halus, atrofi pankreas, penurunan daya tahan tubuh serta gangguan absorbsi zat makanan. Sebaliknya diare yang dapat menjadi faktor risiko malnutrisi disebabkanantara lain: asupan makanan penderita diare menurun sebagai akibat dari kebiasaan ibu yang menghentikan makanan tertentu selama diare, adanya anoreksia, kebiasaan mengencerkan susu selama diare, berkurangnya absorbsi makanan, kehilangan langsung zat makanan melalui usus dalam bentuk tinja, bertambahnya kebutuhan zat makanan oleh tubuh karena terjadi peningkatan katabolisme serta kehilangan cairan dan elektrolit dalam jumlah banyak dan dalam waktu relatif singkat. ${ }^{13}$ Pada penelitian ini didapat sebagian besar penderita diare anak mempunyai status gizi baik hal ini mungkin disebabkan oleh beberapa faktor, salah satunya adalah penyebab diarenya sendiri.

Berdasarkan karakteristik tinja pasien diare anak didapatkan konsisitensi sebagian besar tinja anak adalah lembek. Konsistensi tinja kadang dapat menentukan penyebab diare. Pada diare yang disebabkan oleh virus biasanya tinja cair dan berbau asam, sedangkan pada diare yang disebabkan oleh amuba karakteristik tinja biasanya tinja berlendir, berdarah dan berbau amis, sedangkan pada diare yang disebabkan oleh bakteri tinja berlendir dengan frekuensi defekasi lebih sering daripada yang disebabkan oleh amuba serta berbau busuk. Pada diare yang disebabkan oleh protozoa usus oportunistik, kosistensi tinjanya cair. ${ }^{7}$ Konsisitensi tinja yang lembek tidak khas untuk dapat menentukan etiologi diare, harus dilihat lagi apakah ada darah atau lendir. Kalau ada darah dan lendir kemungkinan penyebab diarenya adalah amuba atau bakteri seperti yang disebutkan sebelumnya. Konsistensi tinja lembek dan tidak ada darah dan lendir kemungkinan pasien tersebut baru terserang diare, sehingga ampas tinjanya masih banyak.

\section{KESIMPULAN}

Berdasarkan hasil penelitian ini didapatkan bahwa kejadian diare banyak terjadi pada anak dengan jenis kelamin laki-laki dan pada usia balita terutama dibawah tiga tahun.Status gizi pada anak dengan diare sebagian besar adalah baik. Karakteristik tinja pada penderita diare anak di Puskesmas Rawat Inap Pekanbaru sebagian besar lembek, tidak berlendir dan tidak berdarah. Selanjutnya perlu dilakukan penelitian lebih lanjut tentang penyebab diare dan manifestasi klinis yang terjadi.

\section{PENUTUP}

Ucapan terimakasih kepada Lembaga Penelitian Universitas Riau, Dekan Fakultas Kedokteran Universitas Riau dan Kepala Puskesmas Rawat Inap Pekanbaru, serta seluruh pihak yang telah membantu penelitian ini. 


\section{DAFTAR PUSTAKA}

1. Kusbaryanto, Hidayati T. Gambaran kejadian wabah diare dan faktor-faktor terkait di Senden, kulon, Progo. Jurnal Kedokteran dan Kesehatan Mutiara Medika 2008;8(1).

2. Dinas Kesehatan Provinsi Riau. Profil Kesehatan Provinsi Riau.2009.

3. Mansjoer et al. Bagian Ilmu Kesehatan Anak FKUI. Ilmu Kesehatan Anak, Jilid I. Jakarta: Infomedika Jakarta, 1998. 283-8

4. Putra DS. Diare Akut pada Anak. http://www.drrocky.com/layout-artikel...../42-diare-akut-padaanak

5. Susanto L, Gandahusada S, Coccidia. Dalam Parasitologi Kedokteran. Ed:4. Jakarta: Balai Penerbit FKUI; 2008: 158-79.

6. Akibat Perubahan Iklim, 1500 Orang Menderita Diare Setiap Minggu. 2007; http:// www.riau.go.id

7. Mansjoer et al. Bagian Ilmu Kesehatan Anak FKUI. Ilmu Kesehatan Anak, Jilid I. Jakarta: Infomedika Jakarta: 1998. 283-8
8. Gandahusada S, Pribadi W, Ilahude D. Parasitologi Kedokteran. Fakultas Kedokteran Universitas Indonesia. Jakarta: 1998

9. Palupi A, Hadi H, SoenartoSS. Status gizi dan hubungannya dengan kejadian diare pada anak diare akut di ruang rawat inap RSUP Dr.Sardjito Yogyakarta.Jurnal Gizi Klinis Indonesia 2009; $6(1): 1-7$.

10.Pudjiadi S. Ilmu gizi klinis pada anak. Jakarta: Balai Penerbit FKUI:2000.

11.Primayani D. Status gizi pada pasien diare akut di ruang rawat inap anak RSUD SoE Kabupaten Timor Tengah Selatan NTT. Sari Pediatri 2009; 11 (2): 90-3.

12. Adisasmito W. Faktor risiko diare pada bayi dan balita di Indonesia: Systematic review penelitian akademik bidang kesehatan masyarakat. Makara kesehatan 2007; 11 (1); 1-10.

13.Departemen Kesehatan RI. Direktorat Jenderal Pemberantasan Penyakit Menular dan pengelolaan lingkungan pemukiman. Buku ajar diare. Jakarta: departemen Kesehatan RI;1999. 